\title{
THE WORLD'S PARLIAMENT OF RELIGIONS
}

The East/West Encounter, Chicago, 1893

\section{Richard Hughes Seager}

The 1893 World's Parliament of Religions was conceived as a presentation of all the major religions of the time, with the goal "to unite all religion against irreligion." Seager's beautifully fashioned narrative explores this fascinating event in all its complexities and shows it to be truly a watershed event in the creation of a more pluralistic religious culture in America.

Religion in North America

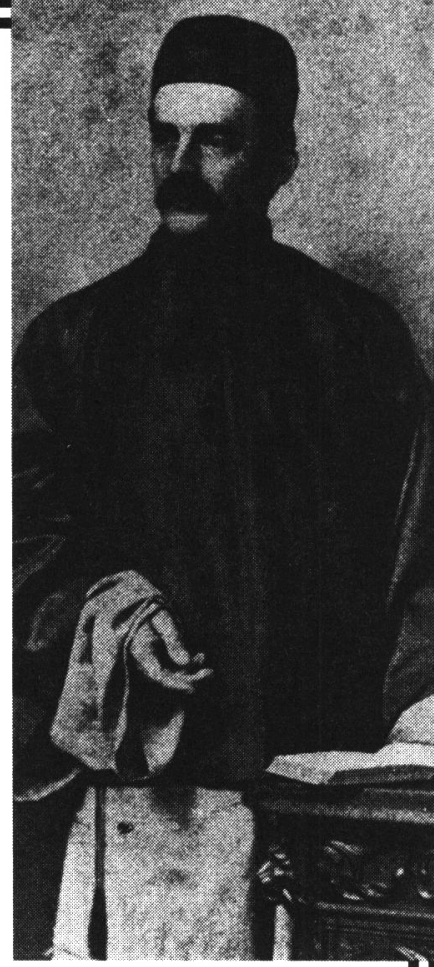
160 pages, 17 b\&w photos, cloth $\$ 27.50$

Now in paperback!

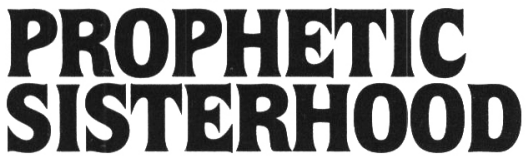

Liberal Women Ministers of the

Frontier, 1880-1930

\section{Cynthia Grant Tucker}

An inspiring account of Unitarian and Universalist clergywomen on the western frontier in the nineteenth century. Their questioning of traditional roles led to the creation of a domestic ministry whose scope extended far beyond the pulpit to suffrage, social settlements, and the peace movement. But because they were women, they failed to gain institutional acceptance.

\section{2 pages, paper $\$ 14.95$}




\section{THE PHILOSOPH EDWARDS}

A Study in Divine Semiotics Stephen H. Daniel

"In this challenging work, Daniel draws on the semiotics of Foucault, Kristeva, and Peirce to explore Edwards's typology. ... elegant and important ..."

- Library Journal

"The identification of the dichotomy between the Renaissance and Modernist modes of logic and the detailed working

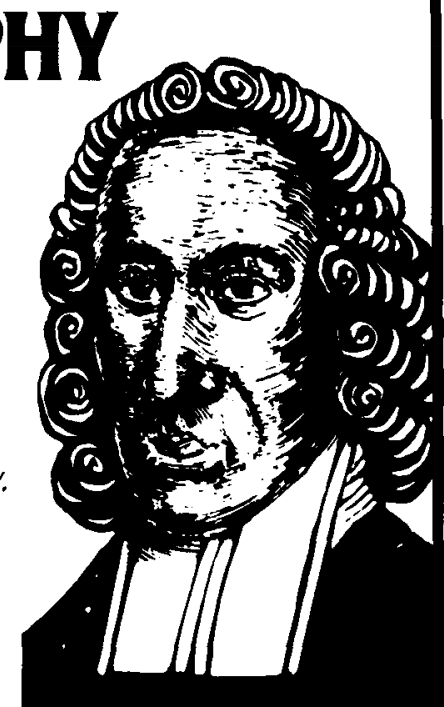
out of that dichotomy in Edwards's writings constitute a new foundation for the study of Edwards's thought and rhetoric." -Wilson H. Kimnach Indiana Series in the Philosophy of Religion 224 pages, cloth $\$ 22.95$

\section{FROM SIN TO SALVATION}

Stories of Women's Conversions, 1800 to the Present

\section{Virginia Lieson Brereton}

"... fascinating..." - Theological Book Review

By examining women's conversion experiences, the author provides a corrective to the much popularized TV evangelism. She examines the stories U.S. women have told of their profound realization of their sinfulness and the necessity of turning to God's grace and love for forgiveness.

\section{6 pages}

paper $\$ 4.25$

(also in cloth $\$ 29.95$ )
At bookstores or from

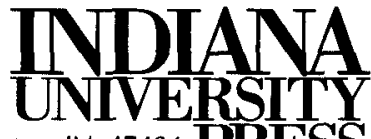

Bloomington, IN 47404 PRESS Orders: 1-800-842-6796 


\section{The Boundaries \\ of Memory:}

\section{The United States Holocaust}

\section{Memorial Museum}

An exhibition review by

Edward T. Linenthal

appearing in the

September 1994 issue of

\section{American Quarterly}

(Volume 46, Number 3)

Lucy Maddox, Editor,

Georgetown University

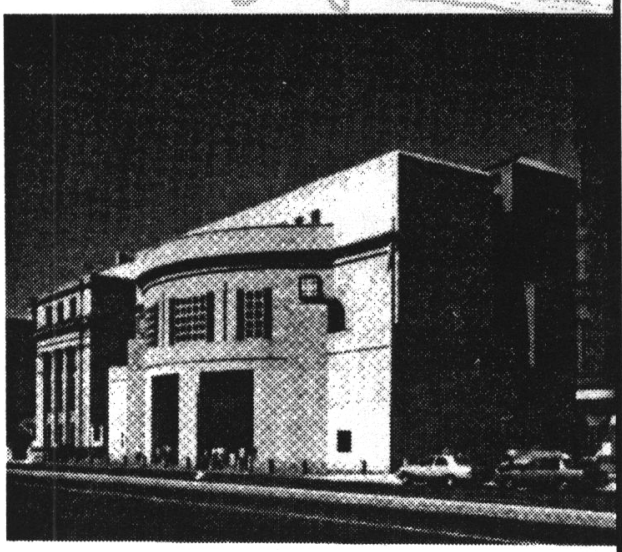

Mary Corbin Sies, Associate Editor, University of Maryland

As the official publication of the American Studies Association,

American Quarterly promotes a broad humanistic understanding of

American culture and encourages cross-disciplinary work. In addition, the journal features retrospectives and exhibition and book reviews.

Published quarterly in March, June, September and December.

Prepayment is required.

Single-issue price for Vol. 46, No. 3: $\$ 8.50$, individuals; $\$ 17.00$, institutions. Annual Subscription: Individual subscription included in ASA membershipplease call or write for more information; $\$ 59.00$, institutions.

Foreign postage: $\$ 3.90$, Canada \& Mexico; $\$ 9.00$, outside North America.

Payment must be drawn on a U.S. bank in U.S. dollars or made by international money order. MD residents add 5\% sales tax. For orders shipped to Canada add 7\% GST (\#124004946).

Send orders to:

The Johns Hopkins University Press, PO Box 19966, Baltimore, MD 21211.

Call toll-free 1-800-548-1784, Mon.-Fri, 8:00-5:00 ET for VISA or MasterCard orders. Or FAX your order anytime: (410) 516-6968. E-mail address for VISA and MasterCard orders only: jlorder@jhunix.hef.jhu.edu

7h Published by The Johns Hopkins University Press 

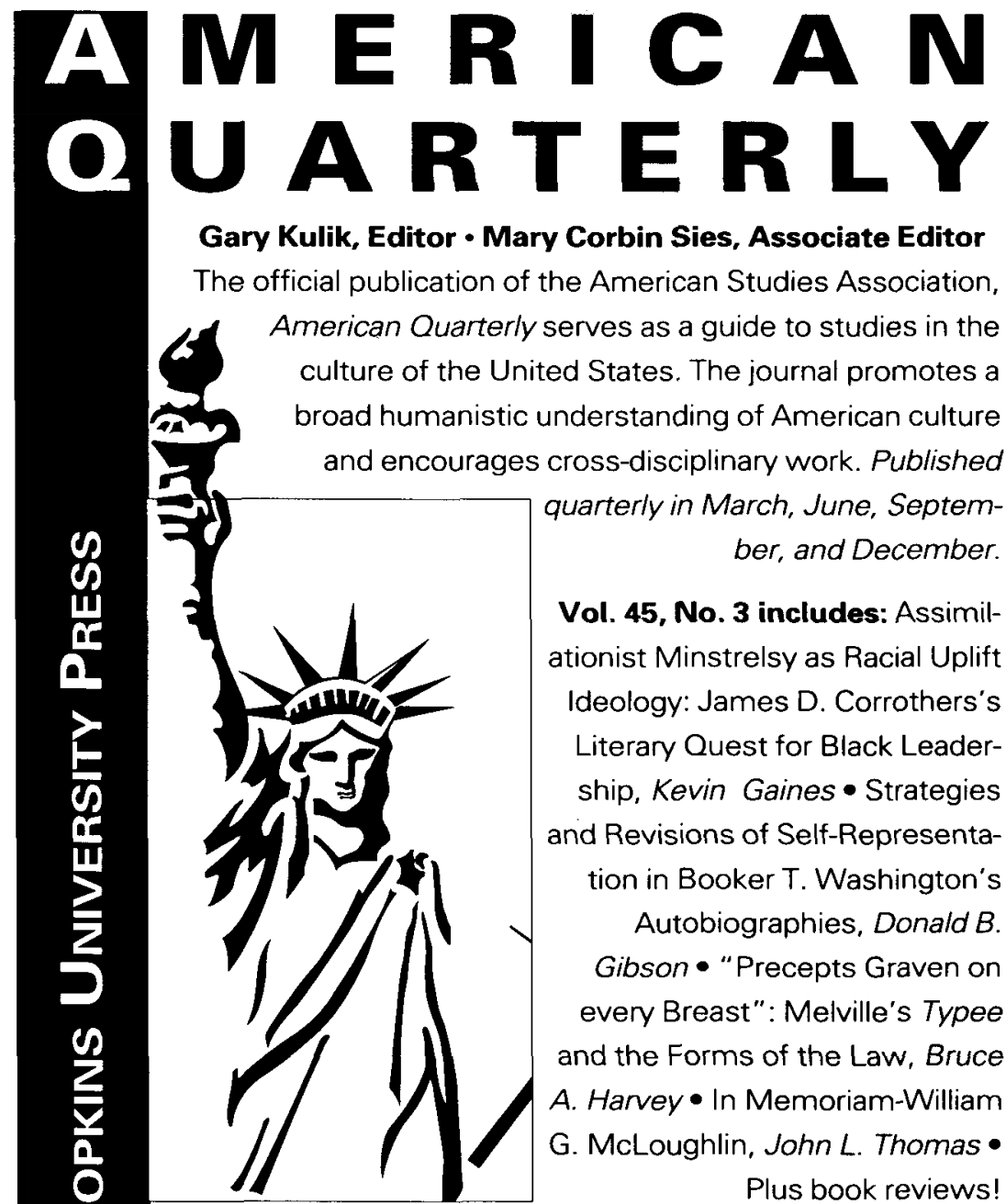

Gary Kulik, Editor - Mary Corbin Sies, Associate Editor

The official publication of the American Studies Association, culture of the United States. The journal promotes a road humanistic understanding of American culture and encourages cross-disciplinary work. Published quarterly in March, June, September, and December.

Vol. 45, No. 3 includes: Assimilationist Minstrelsy as Racial Uplift Ideology: James D. Corrothers's Literary Quest for Black Leadership, Kevin Gaines • Strategies and Revisions of Self-Representation in Booker T. Washington's Autobiographies, Donald B. Gibson - "Precepts Graven on every Breast": Melville's Typee and the Forms of the Law, Bruce A. Harvey $\bullet$ In Memoriam-William G. McLoughlin, John L. Thomas• Plus book reviews!

Prepayment is required. Annual subscriptions: Individual subscription included in ASA membership; please call or write for more information: $\$ 55.50$, institutions. Foreign postage: $\$ 4.00$, Canada \& Mexico; $\$ 10.30$, outside North America. Single-issue prices: $\$ 8.50$, individuals; $\$ 17.00$, institutions. Payment must be drawn on a U.S. bank in U.S. dollars or made by international money order. MD residents add $5 \%$ sales tax. For orders shipped to Canada add 7\% GST (\#124004946).

Send orders to: Johns Hopkins University Press, PO Box 19966, Baltimore, MD 21211.

Z Ordering by VISA or MasterCard? For fastest service, call toll-free 1-800-548-1784, Mon.-Fri., 8:00-5:00 ET or FAX us anytime: (410) 516-6968. 


W. S. F. Pickering, editor
This volume brings together the
most comprehensive selection
yet available of Émile
$\begin{aligned} & \text { Durkheim's writings on religion. } \\ & \text { Besides helping to establish the } \\ & \text { discipline of sociology in } \\ & \text { France, Durkheim is widely } \\ & \text { recognized as one of the found- } \\ & \text { ing figures in the modern study } \\ & \text { of religion. The volume contains } \\ & \text { a new translation of important } \\ & \text { sections of The Elementary Forms } \\ & \text { of Religious Life (1912) and a } \\ & \text { selection of Durkheim's early } \\ & \text { reviews, articles and extracts } \\ & \text { from books, presented in } \\ & \text { order of original publication. }\end{aligned}$
van Gennep, Goldenwieser, Stanner, and, for the first time
in English, by the French sociologist Gaston Richard.
Paper: \$19.95 1 -800-437-6692




\section{Jewish Social Studies}

history,

culture, and society
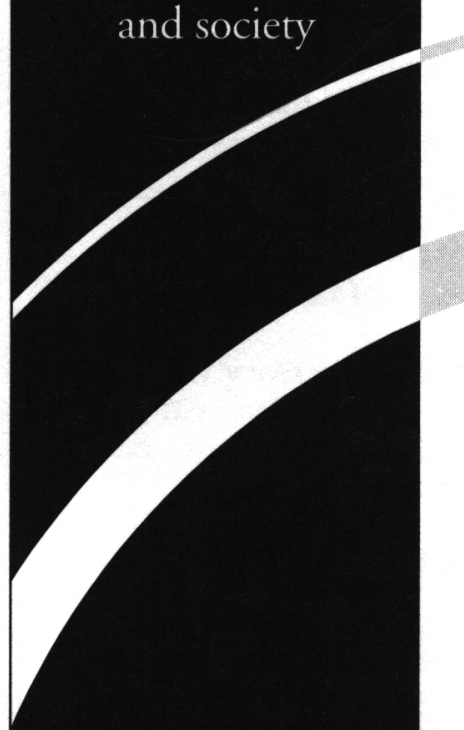

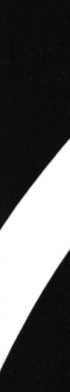

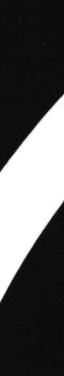
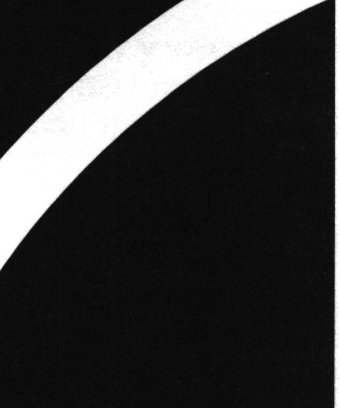

\section{THE NEW SERIES} Aron Rodrigue and Steven Zipperstein

Volume 1, Number 1

\section{Edited by}

David Biale: "Confessions of an Historian of Jewish Culture"

Mitch Cohen: "A Preface to the Study of Jewish Nationalism"

Arnold M. Eisen: "Rethinking Jewish Modernity"

Daniel Gutwein: "Economics, Politics and Historiography: Hayyim D. Horowitz and the Interrelationship of Jews and Capitalism"

Hillel J. Kieval: "Representation and Knowledge in Medieval and Modern Accounts of Jewish Ritual Murder"

Ezra Mendelsohn: "Should We Take Notice of Berthe Weil?: Reflections on the Domain of Jewish History"

Naomi Seidman: "Carnal Knowledge"

Subscriptions (3 issues): individuals, $\$ 45.00$ institutions, $\$ 65.00$

\section{INDIANA UNIVERSITY PRESS}

601 North Morton Street Bloomington, Indiana 47404 Phone (812)855-9449, Fax (812)855-7931 Email Journals@Indiana.Edu 


\section{PROOFTEXTS \\ A Journal of Jewish Literary History}

Editors:

Alan Mintz, University of Maryland

David Roskies, Jewish Theological Seminary of America.

\section{SPECIAL ANNIVERSARY OFFER!}

Last year, Prooftexts celebrated its tenth anniversary with a special volume that invited past contributors from around the world to sum up important research or strike out in new directions. The result was three double-sized issues that covered Jewish literature throughout history. Contributions ranged from "The Sack of Schechem: The Use of Typology in Biblical Covenant Religion" to "Feminism Under Siege: The Vicarious Selves of Israeli Women Writers."

Now you can get all or part of this special anniversary volume FREE when you subscribe to Prooftexts. Enter a new two-year subscription and get all three issues FREE. Or subscribe for one year and we'll send you one of these special issues FREE.

Prooftexts is published in January, May, and September.

YES! Please enter my new two-year subscription to PROOFTEXTS and send me the complete anniversary volume FREE. (Offer good while supplies last.)

$\square \$ 38.00$, individuals

$\square \$ 90.00$, institutions

$\square$ YES! Please enter my new one-year subscription to PROOFTEXTS and send my choice of the special issues. (Call Darla Dimitri, 301-338-6944, for information on contents.)

$\square \$ 19.00$, individuals

$\square \$ 45.00$, institutions

$\square$ Check or money order enclosed payable to the Johns Hopkins University Press.

$\square$ Charge my: $\square$ VISA $\square$ MasterCard

Exp. date

Acct No. :

Signature:

Name

Address

City/State/Zip

Country

Prepayment required. Subscribers in Canada and Mexico, add $\$ 3.70$ postage per year; outside North America, add $\$ 6.20$ per year. Charge orders only call toll-free: 1-800-537-JHUP. MD residents add 5\% sales tax. 
